\title{
Arabernes bristede drømme
}

\section{Af Hanna Ziadeh}

Araberne har set deres drømme om frihed, enhed og socialisme briste. Irakerne har i lighed med syrerne og en del andre arabiske nationer oplevet, hvordan deres herskende eliter misbruger de smukke idealer såsom uafhængighed fra Vesten og pan-arabisk enhed til at promovere egne sekteriske interesser. Men trods nutidens gruelige realiteter er det vigtigt at huske på Iraks historie med sameksistens mellem sunnitter og shiitter.

Det er blevet svært på det seneste at skrive om Irak, hvis præmissen for forståelsen af dette lands nutid og fortid ikke er de sekteriske opdelinger og konflikter, især mellem sunnitterne og shiitterne. Ikke desto mindre har den sekteriske forklaringsmodel været et tabu i det meste af Iraks moderne historie. Man måtte ikke søge forklaringen på den uafbrudte kamp om magten og de talrige militærkup i Bagdad i forholdet mellem shiitterne og sunnitterne, ja selv det at nævne i det offentlige rum, at nogen var shia eller sunni, var ligefrem odiøst. Lige så optaget verden og irakerne selv nu er blevet af at definere sig selv og forklare deres handlinger baseret på de sekteriske tilhørsforhold, lige så optaget var iraker- ne indtil 1970'erne med at undertrykke den sekteriske forklaringsmodel.

Hvorfor? Var det fordi irakerne for en kort stund kollektivt havde glemt den tusindårige sekteriske strid, som har delt muslimerne siden dengang for 13 århundreder siden, da profetens barnebarn Imam Hussein blev martyriseret af umayadernes Kalif Yazid ved Kerbala syd for Bagdad? Næppe. Shiitterne holdt det minde levende hvert eneste år i deres sørgeoptog i Ashura. Denne form for glemsel er fysisk umulig for irakerne. Hele Sydirak er ét stort mindesmærke over shiitternes tragiske historie. Fra Samara i nord til Basra i syd er der helligdomme, som årligt forvandles til valfartssteder, der markerer den oprindelige uret mod Imam Hussein samt martyrdommen af de imamer, der efterfulgte ham.

Er det mon fordi irakerne har været mere 'politisk korrekte' før i tiden, eller var det fordi tidsånden var anderledes, da både verden og araberne var fremadskuende og higede efter det moderne og vendte ryggen til historiens lange, mørke skygger? Ja, måske begge dele er rigtige. Men den afgørende faktor er, at araberne generelt og irakerne i særdeleshed var

Hanna Ziadeh er ph.d. og seniorrådgiver ved Institut for Menneskerettigheder. 
travlt optaget af et andet projekt: den nationale befrielse fra kolonimagterne og opbygningen af den store arabiske nation.

For at forstå sejren for den sekteriske forklaringsmodel og de sekteriske tilhørsforholds dominans, og for at forstå nederlaget for tilhængerne af moderniseringen - det som mange så nedladende i øst og vest kalder 'vestliggørelsen' - af det irakiske samfund til fordel for bloddryppende sekteriske og stærkt religiøse alternativer, hvoraf Islamisk Stat kun er det seneste og det værste skud, skal man søge forklaringen i det forfejlede irakiske stats- og nationalopbygningsprojekt.

Der er klare fordele ved at fremhæve denne forklaring. For det første kan vi derigennem opdage historikken bag de nu yderst betændte sekteriske forhold, som ofte bliver fremstillet som en urfejde baseret på århundredgamle religiøse eller teologiske stridigheder, en blodig arv som irakerne er skæbnebestemte til at gentage i endnu blodigere versioner.

For det andet forklarer den moderne nationalstats sammenbrud den forhekselse af den religiøse fortælling og higen efter at vende tilbage til den gyldne islamiske fortid, som både shiitterne og sunnitterne udviser. Begge sider af forklaringen er vigtige, hvis man vil forsøge at forstå politik i Irak og i den arabiske verden, ikke ud fra sunnitternes higen efter at leve som på profetens tid eller shiitternes trang til at hævne profetens barnebarn, men derimod ud fra en mere realistisk samtidig afklaring af de forskellige etniske og religiøse gruppers rettigheder, eliternes magtdeling og irakernes økonomiske og sociale interesser.

Kort sagt, at søge forklaringen bag de tilspidsede sekteriske forhold i det forfejlede stats- og nationalopbygningsprojekt er den eneste forklaringsmodel, der tillader både irakerne og resten af verden at gøre noget konstruktivt.

\section{Et arabisk foregangsland}

Irak, som nu overvejende betragtes som legemliggørelse af en 'failed state', var engang et arabisk foregangsland. Irak var det første arabiske land til at opnå selvstændighed og fuldt medlemskab af Folkeforbundet i 1932. Det som de færreste arabere og selv irakere husker er, at Irak var det arabiske land, som efter Første Verdenskrig nægtede at ligge formelt under for det mandatsystem, som kun de heldigste ikke -europæiske eller amerikanske lande fik lov til at undgå, hvis de da ikke bare var kolonier eller protektorater.

Irakerne, både shiitterne og sunnitterne, gav briterne kamp til stregen, efter de besatte landet i 1917 og forsøgte at gøre Irak til en af deres lydstater. Irakerne nægtede at acceptere mandatsystemet og fik i stedet et kongedømme ledet af den dengang mest folkelige arabiske nationale leder, Kong Faisal (fra 1921 til hans død 1933), der fire år efter sin tronbestigelse proklamerede én af de tidligste moderne arabiske forfatninger. Før Libanon, Syrien og kun et år efter Egypten.

Hvorfor indvilgede det shiitiske flertal i 1921 i, at briterne satte en sunni-fyrste fra Mekka på Iraks trone? Det var bestemt ikke, fordi de var underkuede: shiitterne i Sydirak udkæmpede et legendarisk oprør mod den britiske besættelse mellem 1918 og 1920. Denne revolution var ledet af ayatollaherne i den hellige by Najaf, men de formåede at samle også sunnitterne bag sig.

Sunni-shia alliancen bag Kong Faisal var begrundet i to forhold, som havde samlet araberne - både eliter og masser i de forrige to århundreder: et brænden- 
de ønske om at gøre sig fri fra fremmede magter, især de vestlige, og en drøm om at oprette en fælles arabisk stat, som skulle fungere som en genoprettelse af deres nationale storhed, men også sørge for modernisering, økonomisk fremgang og social retfærdighed. Iraks shiitter så - næsten i lige så høj grad som sunnitterne den sunnitiske Faisal først og fremmest som en national arabisk helt. Shiitter som sunnitter så hans kongemagt som første etape af frigørelsen fra briternes besættelse og i opbygningen af den arabiske fælles stat, som hans far, Sharifen af Mekka, havde fået tilsagn fra de allierede om, at araberne skulle have som belønning for deres 'jihad'. En jihad som Sharif Hussein (1854-1931) erklærede imod den islamiske kalif i Istanbul i 1916 under Første Verdenskrig.

Hvad gik så grueligt galt mellem shiitterne og sunnitterne, der kan forklare, at de hver på sin side nu søger et samfund, som ekskluderer, dæmoniserer og endda udrydder den anden part?

\section{Liberal sekterisme}

Igennem mit studie af de skiftende irakiske forfatninger, Sectarianism and Intercommunal Nation-Building in Iraq, 1921 2014, har jeg kunnet spore, hvordan de magthavende eliter, både de historisk herskende sunnitter og deres shiitiske partnere, opbyggede et hierarki af politiske privilegier og sociale rettigheder, som de cementerede ved at ty til lejlighedsvise sekteriske mobiliseringer.

Den religiøst baserede statslegitimitet, der herskede i de irakiske provinser under det ottomanske kalifat, og som så en arabisk sunni-elite som de naturlige herskere, blev videreført af Kong Faisal og hans panarabiske officerer. Under dække af arabismen og opbygningen af den store ara- biske nation tillod Kong Faisal, at den ny stat, dens administration og især dens hær blev opbygget langs sekteriske linjer. For eksempel var det først i 1940'erne, at kongen udpegede en premierminister fra en shiitisk familie. Lidt har det hjulpet, da kongen sad tungt på magten, og alle de højtstående stillinger i staten blev besat af sunnitterne.

Denne sekteriske tendens blev forstærket yderligere helt op til Anden Verdenskrig, da den traditionelle herskende elite, dvs. notabiliteter, store jordejere og købmænd i suq'en, så deres magtbase truet som følge af det irakiske samfunds hurtige modernisering, der for alvor tog til efter statsoprettelsen.

Verden og medierne var ofte optaget af de synlige, markante fornyelser, som det irakiske samfund og de enkelte irakere formåede at gennemføre på en kort tid. Den irakiske stat kunne i de første 20 år af dens historie prale af oprettelse af politiske partier, valg til parlamentet, udgivelse af aviser, indførelse af blandede skoler, inddragelse af kvinderne i det offentlige liv. Irak oplevede, at moderniteten blev gennemført meget hurtigere end i de arabiske nabosamfund, som havde samme konservative, stammebaserede samfundsstruktur som Irak.

Men det vigtigste var, at moderniseringen bragte nye sociale grupper frem fra periferien til centrum. Under monarkiet (1921-1958) oplevede millioner af irakere på et par årtier en forvandling, som ofte tager mange generationer. En samfundsmæssig forandring, der så dem blive forvandlet fra fattige, ubemyndigede bønder eller stammemedlemmer i afsondrede, fattige landområder, hvor både sunnitter og shiitter lå hjælpeløst under for rige landejere og autoritære stammeledere, til i stigende grad at være urbaniserede og be- 
myndigede borgere med adgang til skoler, presse, partier.

Allervigtigst oplevede irakerne en forvandling, hvor sunnitterne og shiitterne i højere grad kom til at leve i blandede boligkvarterer, arbejdspladser og skoler etc. Som følge af den forandring opstod nye, sekterisk blandede, selvbevidste sociale grupper af statsansatte, arbejdere og småhandlende. De herskende sekteriske eliter formåede ikke at integrere disse nye grupper i det ny nationale stats politiske system. I stigende grad gjorde de herskende eliter alt for at berige sig ved at tilegne sig statens ressourcer. Alt imens afstanden i levevilkår mellem de herskende og herskede steg, skrumpede den fysiske afstand mellem, hvor de fattige og de rige boede. Det gjorde, at oplevelsen af de sociale forandringer blev mere dramatisk.

De sekteriske eliter under det liberale kongelige regime nægtede at dele magten med de ny sociale grupper og forsøgte med autoritære metoder at holde dem underkuet. Det er denne politiske eksklusion, der sendte de progressive, tværsekteriske sociale grupper i armene på radikale, anti-sekteriske ideologier. Disse ideologier, den pan-arabiske nationalisme (nasserismen og Baath-partiet), socialismen og kommunismen oplevede en opblomstring i den arabiske verden lige før og især efter Anden Verdenskrig.

Det fik det irakiske samfund ind i en ond spiral, for jo mere radikale de ny sociale grupper blev, jo mere hårdnakkede blev de sekteriske eliter i deres bestræbelse på at holde dem væk for statsmagten, hvilket kun forstærkede de ekskluderede gruppers politiske radikalisering.

Det mest effektive redskab for de traditionelle herskende eliter var at bruge sekterisk og etnisk mobilisering i et forsøg på at dele de nu stærkt ideologiserede mas- ser. Vi skal huske, at i 1950'erne var Det Irakiske Kommunistparti det største kommunistparti i Mellemøsten, især blandt de underprivilegerede shiitter i syd og kurderne i nord.

Sekterisk mobilisering var det primitive ledelsesredskab, som de truede sekteriske eliter tyede til for at genskabe legitimitet. Imidlertid led dette irakiske sekteriske system af et strukturelt grundproblem, idet det var en minoritet, den sunni-arabiske elite, som historisk sad på magten $\mathrm{i}$ Bagdad.

Tildeling af status og ressourcer var baseret på sekteriske tilhørsforhold. Systemet blev legitimeret ved, at det var som medlemmer af en privilegeret sekt, at irakerne kunne fă del i disse goder, og ikke som følge af statsborgerskab. Det sekteriske system kunne tilfredsstille en del sunni-arabere samt en del velhavende shiitter, som accepterede rollen som juniorpartnere. Men det kongeligt priviligerede sekteriske system kunne ikke imødekomme behov og krav hos flertallet af shiitter, kurdere og en del sunni-arabere.

Tiltagende brug af sekterisk mobilisering lettede periodevis presset på de sekteriske eliter, men begge de sekteriske eliter og deres konkurrenter begyndte at ty til at bruge militæret til at opnå deres politiske mål. Segmenteringen af Iraks nye nationalsamfund i konkurrerende sekter, etniske grupper og stammer fandt en naturlige allieret i militariseringen af den nationale politiske sfære.

\section{Revolutionær sekterisme}

Den sekteriske politik, der udvikledes under det liberale kongedømme, og som nægtede politisk at inkludere de ny sociale grupper, blev videreført af deres revolutionære repræsentanter, de såkaldte Unge Officerer, som i folkets navn over- 
Saddam videreførte den sekteriske og etniske mobilisering i dens yderste konsekvens. Han førte mangeårige undertrykkelseskampagner mod kurderne i nord, der kulminerede med gasangrebene i Halabja i 1988, og mod shiitterne i syd, der kulminerede med massive nedslagtninger i 1992.

tog magten i 1958. Dog har den revolutionære sekterisme den tilføjelse, at de national-socialistiske militære regimer, især under deres sidste manifestation med Saddam som leder, udviklede en styreform som ikke accepterede nogen form for opposition eller respekt for de fundamentale personlige friheder.

Til trods for at de revolutionære regimer gennemførte omfattende sociale reformer, hvoraf landbrugsreformen var den vigtigste, der imødekom massernes krav om større social retfærdighed, faldt de ny magthavere tilbage på den sekteriske mobilisering for at cementere deres hold over statsmagten. En statsmagt, som i stigende grad i kraft af de nationaliserede olieindtægter kom til at betyde enorme rigdomme for den gruppe eller sekt, der sad på magten.

Militærkuppet, der afskaffede monarkiet og likviderede hele den kongelige familie, var pro-shiitisk og blev støttet af kommunisterne. Med slogans om demokrati og social retfærdighed etablerede den folkelige leder Abdel Karim Kassim (19581963) en militær styreform, som dækkede over de sekteriske tilhørsforhold med retoriske tåger om de dengang for de fleste arabere uimodståelige drømme om socialisme og pan-arabisk enhed.

Det var under den ellers mest moderate militære leder af Irak, at de første åbne, blodige sunni-shia konflikter fandt sted. Det var det såkaldte Mosul-oprør i 1959, hvor sunnitterne overtog magten i sektens højborg i Irak. (Bemærk, at det er Mosul igen som blev overtaget af sunnitterne i 2014, og hvorfra 'Kalif' Al Baghdadi proklamerede sin Islamiske Stat). Kassim kvalte oprøret med blod, men sunnitterne blev radikaliserede og så ham som shiitternes og kommunisternes lakaj. Sunnitterne fik hurtigt deres hævn ved militærkuppet i 1963, hvor man mener det amerikanske CIA udleverede navnelister over de overvejende shiitiske Kassim-støtter, der blev likvideret i hundredevis.

Saddam videreførte den sekteriske og etniske mobilisering i dens yderste konsekvens. Han førte mangeårige undertrykkelseskampagner mod kurderne i nord, der kulminerede med gasangrebene i Halabja i 1988, og mod shiitterne i syd, der kulminerede med massive nedslagtninger i 1992.

Det, der begyndte under Kassim i 1959 som en mindre sekterisk episode, blev værre og blodigere under de talrige militære ledere, der efterfulgte ham, og som alle overtog statsmagten som følge af slet skjulte sekteriske eller stammebaserede magtkampe. Fra at sekterisme var et stigma, som ingen ville have på sig, var det vokset til en statspraksis, først under det liberale kongedømmes undergang og dernæst de revolutionære militære regimer. Til slut blev sekterisme til Iraks statsideologi, først under krigen mod Iran (19811988) og endnu mere efter at shiitterne i 1992 rejste sig imod Saddam i kølvandet på Kuwait-krigen.

\section{Demokratisk sekterisme}

Saddam-regimets endeligt, der indtraf efter amerikanske tanks indtog Bagdad i april 2003, skulle ifølge 'De Villiges Koalition', der deltog i invasionen, afslutte den sekteriske tradition og indføre demokrati. Nothing less. I stedet har amerikansk 
magtfuldkommenhed og historieløshed sammenkoblet med de regionale indblandinger fra Iran og Saudi-Arabien formået at videreføre Saddams virale form for voldelig sekterisme.

Irak fik i 2005 en på mange måder demokratisk forfatning. En forfatning, hvor islam er statens religion og fundament for lovgivning. No problem. Man hører få protester i Mellemøsten, når man nævner islam, men ser man nærmere på, hvilken islam den irakiske forfatning gjorde til fundament for den demokratiske stat, som Vesten støttede med blod og tårer, så er det en shiitisk islam. En forfatning, der ophøjer shiitternes hellige byer og ayatollaher til nationale helligdomme.

Forfatningen genskabte tekstuelt det gamle sekteriske hierarki med særlige politiske privilegier, men denne gang med shiitterne på pyramidens top. Mens deres styrker forblev i Irak, kunne amerikanerne afholde shiitterne fra at fuldføre deres hævn over de historiske uretfærdigheder, som Saddam og sunnitterne havde udsat dem for.

Amerikanernes tilbagetrækning i 2007 medførte et sekterisk shiitisk diktatur under dække af numerisk demokrati. De iranskstøttede shiitiske fraktioner, som amerikanerne udleverede magten til i Bagdad, læste demokratiets drejebog gennem egeninteressens prisme. Iraks premierminister igennem otte år, al-Maliki, og andre shiitiske ledere mente, at demokrati er flertallets styre, shiitterne er flertallet, ergo skal al magten gå til shiitterne. Den herskende shiitiske elite i Bagdad nægter at lede Irak efter de særlige demokratiske principper, der gælder for det multisekteriske og multireligiøse samfund, som de ellers accepterede at indskrive i forfatningen fra 2005. Det er det såkaldte konsensus-baserede system, der skal sikre, at det numeriske flertal ikke bliver oversat til sekterisk diktatur.

Efter iransk indblanding fornægtede den shiitiske elite det historiske kompromis fra 2005, som ellers blev presset ned over sunnitterne af amerikanerne. Det er denne udvikling, der har fodret sunnitternes oprør i de seneste år, og som kulminerede i oprettelsen af Islamisk Stat.

Ofte bliver det kontekst-baserede, historiserende perspektiv, som jeg har skitseret, brugt til at konkludere, at sekterisme bare er politisk konstruktion. Underforstået at en konstruktion er nem at dekonstruere. Not so simple. Tilhørsforhold til en religiøs gruppe, en sekt, er ikke ensbetydende med sekterisme. Sekterisme er det politiske system, der bruger dette gruppetilhørsforhold, ligesom nationalismen gør det, til at definere et forhold mellem staten, samfundet og gruppen, som alle medlemmer i fællesskabets navn bør underordne sig.

De fleste moderne nationalstater, der er baserede på etniske og lingvistiske gruppetilhørsforhold som det danske, har udviklet sig til mere rummelige samfund som følge af en lang proces, hvor udviklingen af retsstaten og retsprincipperne om lighed for loven og, allervigtigst, et lovbaseret borgerskabsbegreb åbnede de nationale stammers rækker for nye medlemmer, individer såvel som grupper. Indtil videre har ingen af de sekterisk baserede stater såsom Libanon, Irak, Iran og Saudi-Arabien (og delvis Israel) formået at udvikle et politisk system, som erstatter sekt-fællesskabets eksklusive omfavnelse med retsstatens medborgerskab.

\section{Bristede drømme}

Når sekterismen hersker så endegyldigt, skyldes det, at araberne har set deres drømme om frihed, enhed og socialisme 
briste. Irakerne har i lighed med syrerne og en del andre arabiske nationer oplevet, hvordan deres herskende eliter misbruger de smukke idealer såsom uafhængighed fra Vesten og pan-arabisk enhed til at promovere egne sekteriske interesser.

$\mathrm{Nu}$ forsøger de samme eliter - og vi skal huske, at de fleste af Islamisk Stats ledere er gamle Baath-medlemmer - at rekruttere irakerne bag endnu et grandiost, altomfattende projekt, der skal se opbygning af det frelste og frelsende religiøse fællesskab. Det sidste valg i Irak viste, at irakerne, især shiitterne, er kørt trætte i de sekteriske partier, ligesom de engang blev trætte af arabiske nationalister.

Desværre har Islamisk Stats opståen samt tilspidsningen af konfrontationen mellem de to store sekteriske magter, det shiitiske Iran og sunnitiske Saudi-Arabien, og de enorme ressourcer, de bruger på sekterisk mobilisering, gjort det svært for de fleste irakere at løsrive sig fra sekterismens kvælende vold.

Til trods for nutidens gruelige realiteter er det vigtigt at huske på Iraks historie om sameksistens mellem sunnitterne og shiitterne, for den fortæller ikke alene, hvordan irakerne samles, men hvordan de splittes. Begge dele som følge af her-ognu politiske beslutninger, og ikke som følge af tidløse teologiske og religiøse stridigheder. 